\title{
Uheldig legemiddelbruk hos eldre
}

Legemidler kan hos eldre mennesker gjøre stor nytte, men også gi skade. Det finnes flere vurderingsinstrumenter når det gjelder legemiddelbehandling av eldre, men de har i liten grad vært i klinisk bruk i Norge. Beers kriterier er mest kjent, men de er utviklet i USA (andre legemidler enn i Norge) og begynner å bli utdatert (1). Nylig er det utarbeidet et norsk vurderingsinstrument for eldre pasienter i primærhelsetjenesten (NORGEP) (2).

Det er behov for et enkelt, praktisk vurderingsinstrument beregnet for eldre i sykehus for å påvise forskrivning av uhensiktsmessige legemidler som kan gi skade. STOPP (Screening Tool of Older People's potentially inappropriate Prescriptions) er et slikt instrument (3). Det er utviklet i Irland og er nå er i bruk i Irland, Storbritannia og en rekke andre europeiske land. Det er validert for bruk hos eldre innlagt i sykehus og har god interraterreliabilitet $(4,5)$.

Vi har oversatt STOPP til norsk, etter gjeldende prosedyre med oversettelse til- bake til engelsk, og justert det slik at det samsvarer med norsk terapitradisjon og kun inneholder legemidler som er godkjent for bruk i Norge.

STOPP i norsk utgave finnes på Norsk geriatrisk forenings hjemmeside (6). Vi håper dette vurderingsinstrumentet vil bli flittig brukt, og tar gjerne imot synspunkter som kan hjelpe oss med å forbedre det.

\section{Anette Hylen Ranhoff \\ ahranhoff@yahoo.no \\ Diakonhjemmet Sykehus 0319 Oslo \\ og \\ Institutt for indremedisin \\ Universitetet i Bergen \\ Marit Stordal Bakken \\ Haraldsplass Diakonale Sykehus \\ Anne Gerd Granås \\ Sabine Ruths \\ Institutt for samfunnsmedisin \\ Universitetet i Bergen}

Oppgitte interessekonflikter: Ingen
Litteratur

1. Fick DM, Cooper JW, Wade WE et al. Updating the Beers criteria for potentially inappropriate medication use in older adults: results of a US consensus panel of experts. Arch Intern Med 2003; 163: 2716-24.

2. Rognstad S, Brekke M, Fetveit A et al. The Norwegian General Practice (NORGEP) criteria for assessing potentially inappropriate prescriptions to elderly patients. A modified Delphi study. Scand J Prim Health Care 2009; 27: 153-9.

3. Gallagher P, Ryan C, Byrne S et al. STOPP (Screening Tool of Older Person's Prescriptions) and START (Screening Tool to Alert doctors to Right Treatment). Consensus validation. Int J Clin Pharmacol Ther 2008; 46: 72-83

4. Gallagher P, O'Mahony D. STOPP (Screening Tool of Older Persons' potentially inappropriate Prescriptions): application to acutely ill elderly patients and comparison with Beers' criteria. Age Ageing 2008; 37: 673-9.

5. Gallagher P, Baeyens JP, Topinkova E et al. Interrater reliability of STOPP (Screening Tool of Older Persons' Prescriptions) and START (Screening Tool to Alert doctors to Right Treatment) criteria amongst physicians in six European countries. Age Ageing 2009; 38: 603-6.

6. Velkommen til nettstedet til Norsk geriatrisk forening. www.legeforeningen.no/geriatri (7.7.2010)

Manuskriptet ble mottatt 7.7. 2010 og godkjent 27.7. 2010. Medisinsk redaktør Anne Kveim Lie. 